\title{
THE
}

\section{JOURNAL OF LARYNGOLOGY,}

\section{RHINOLOGY, AND OTOLOGY:}

\section{A RECORD OF CURRENT LITERATURE}

RELATING TO

THE THROAT, NOSE, AND EAR.

\section{Printed and Published Monthly by}

ADLARD \& SON, Bartholomew Press, Bartholomew Close, London, E.C.

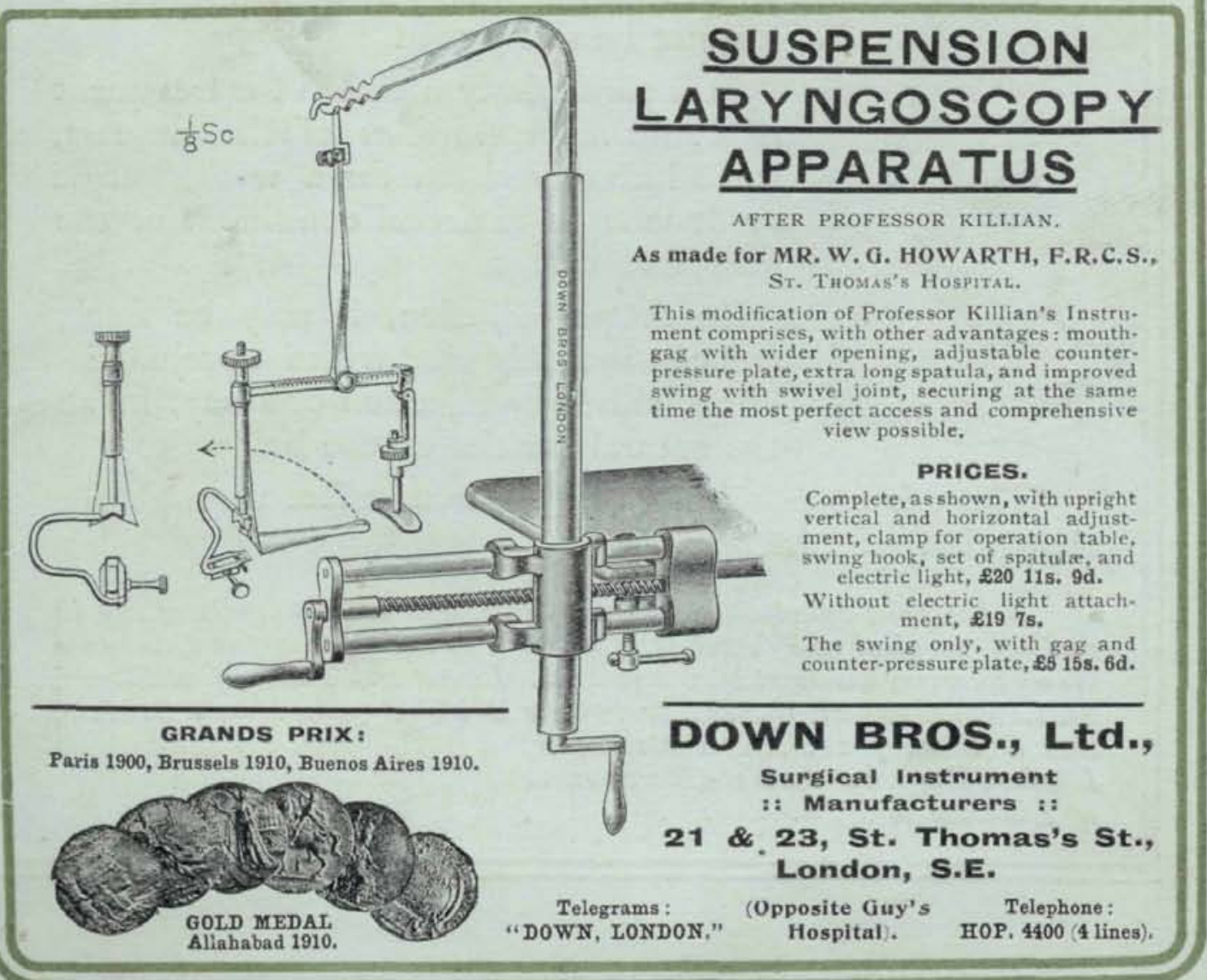

Prepaid Annual Subscription, $f_{1}$ ( 5 dollars) post free. 
We have experimentally proved that Listerine is a powerful antiseptic, preventing the development of bacteria and decomposition of vegetable infusions.-Britis/ Medical Journal, May 3, 1890.

\section{UISTERINE} ANTISEPTIC of known and definite power, prepared in a form convenient for immediate use.

It is a saturated solution of boric acid, reinforced by the antiseptic properties of ozoniferous oils.

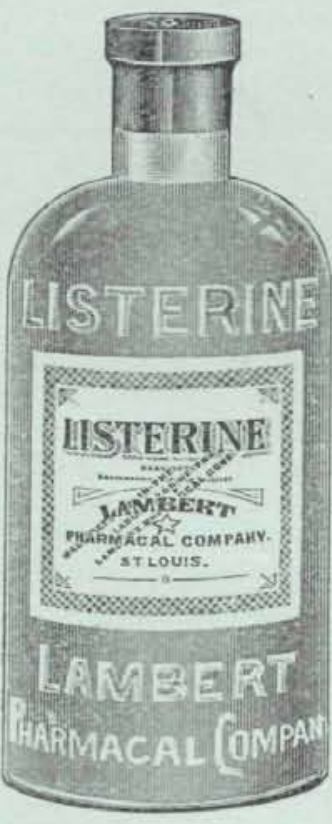

It is unirritating, even when applied to the most delicate tissue.

It does not coagulate serous albumen.

It is quite generally accepted as the standard antiseptic preparation for use where a poisonous or corrosive disinfectant can not be safely used.

It is particularly useful in the treatment of abnormal conditions of the mucosa, and admirably suited for a wash, gargle or douche in catarrhal conditions of the nose and throat.

In proper dilution, it may be freely and continuously used without prejudicial effect, either by injection or spray, in all the natural cavities of the body.

There is no possibility of poisonous effect through the absorption of Listerine.

A pampllet descriptive of the antiseptic, and indicating its utility in medical, surgical and dental practice, may be had upon application to the manufacturers, Lambert Pharmacal Co., Locust and Twenty-first Streets, St. Louis, Missouri, U.S.A., or to their British Agents, Messrs. S. Maw, Son \& Sons, 7-12, Aldersgate Street, London, Eng., but the best advertisement of Listerine is

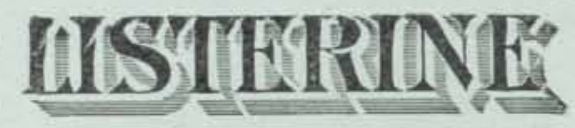




\title{
THE JOURNAL OF LARYNGOLOGY, RHINOLOGY, AND OTOLOGY.
}

Founded in I 887 by MORELL MACKENZIE and NORRIS WOLFENDEN.

\section{A. CHEATLE, F.R.C.S.}

PUBLISHED UNDER THE DIRECTION OF THE EDITORIAL COMMITTEE :

(Pres. Otol. Sect. Internat. Cong. . DUNDAS GRANT, M.A., M.D., F.R.C.S. (London). RICHARD LAKE, F.R.C.S.

J. (Pres. Otol. Sect. R.S.M.). . Glassow: W. MILliGa N, M.D., M.Ch. (Hanchester).
D. R. PATERSON, M.D., M.R.C.P.

Sir StCLIIR THOMSON, M.D., F.R.C.S.(London). (Pres. Laryng. Sect. Internat. Cong.). LOGAN TURNER, M.D. (Edinburgh).

P. WATSON-WILLIAMS, M.D. (Bristol).

MACLEOD YEARSLEY, F.R.C.S. (London).

EDITOR :

DAN MCKENZIE, M.D., F.R.C.S.E. (London),

To a'hon all comminnications showld be addressed.

WITH THE CO-OPERATION UF THE STAFF OF ABSTRACTORS :

Drs. J. Stoddart Barr(Glasgoz), H.S. Birkett (Montreal), Brady (Sydney, N.S.W.) Johi Darling (Edinburgh), Donelan (London), Clayton Fox (London),

J. S. Fraser (Edinburgh), Perry Goldsmith (Toronto), Thos. Guthrie (Liverpool), A. Hutchison (Brighton), J. D. LithGow (Edinburgh), A. MCCall (Boumemouth), Chichele Nourse (London), W. G. Porter (Edinburgh), Price-Brown (7oronto!,

Knowles Renshaw (Manchester), Lindey Seweld. (Manchester),

Alex. R. Tweedie (Nottingham), Raymond Verel (Aberdeen), C. E. West (London), G. Harold L. Whale (London),

WRIGHT (Bristol), and WYLIE (London).

AND THE ASSHSTANCE OF

Mr. George Badgerow (London), Drs. J. Barr (Glasgow), Hugo Frey (Vienna)

A. A. Gray (Glasgow), Grazzi (Florence), Middlemass Hunt (Liverpool),

A. Brown Kelly (Glasgoze), E. Law (London), Masset (Naples),

D. Paterson (Cardiff), Urban Pritchard (London), F. A. Rose (London),

A. Sandford (Cork), Sendziak (Warsaze), H. Tilley (London),

E. WAggetT (London), R. Woods (Dublin).

\section{CONTRIBUTORS TO THIS NUMBER.}

Dr.P. Watson-Willians. |Mr. Raymond Verel. |Mr. H. Clayton Fox.

Mr. Herbert Tillet.

DR. A. Brown KeLLY

Dr. J. B. Horgan.

Dr. J. S. Fraser.

DR. BirketT.

DR. J. Hew AT.

Dr. Knowles Renshaw. Mr. Macleod Yearslet.

\section{MEDICAL GRADUATES' COLLEGE}

\section{AND \\ POLYCLINIC,}

22, Chenies Street, Gower Street, London, W.C.

\author{
PRESIDENT: \\ Sir JAMES CRICHTON-BROWNE, M.D., LL.D., F.R.S.
}

The teachers include members of the Staffs of the General and Special Hospitals and Medical Schools of the Metropolis and elsewhere.

The Demonstrations on Friday afternoons at 4 p.m. are devoted to Diseases of the Throat, Nose, Ear and Eye.

Lecture, May 29, at 5.15 p.m.-Dr. Wyatt Wingrave.- "The Pathology of "Sore Throat.' "'

Annual Subscription, admitting to all Lectures and Demonstrations, One Guinea.

Special Practical Classes are conducted in Otology (Dr. Dan McKenzie), Laryngology

(Mr. J. GAy French), and Rhinology (Mr. StuART-Low), etc.

Pathological Investigations of all kinds are carried out in the Laboratory.

Further Particulars may be obtained from the Medical Superintendent,

Major VinT, M.B., 22, Chenies Street, Gower Street, London, W.C. 


\title{
CONTENTS.
}

Special Articles-

Intranasal Operations for Frontal Sinus Suppuration.-P. WATsonWilliams-(with 3 Plates)

The Intranasal Treatment of Empyema of the Frontal Sinus.-HraberT

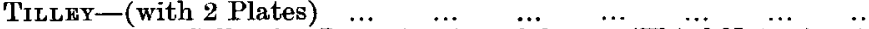

The International Collective Investigation of Ozæna (Third Notice).- $\ddot{A}$. Brown KeLLY $\quad \ldots \quad$... $\ldots$...

Reports for the Year 1913 from the Ear and Throat Department of the Royal Infirmary, Edinburgh. Part IV.-Notes upon the Results Obtained in Two Hundred Consecutive Cases of Acute Otitis Media in which the Schwartze Operation was Performed.-John Hewat...

\section{Societies' Proceedings-}

International Congress of Medrcine.-Section of Otology,-Presidential Address.-Communication by Prof. J. Mouret

\begin{abstract}
s-
Pharrnx.-Local Treatment of Vincent's Angina with Salvarsan.Tonsil Enucleation with the Wire without Preliminary Dissection.The Major Surgery of the Mouth (Tongue and Tonsil) without

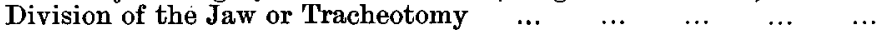

Nose.-The Preparation and Use of Thrombokinase-Large Primary Osteoma of the Frontal Sinus.-Osteomyelitis of the Frontal Bone and Thrombosis of the Longitudinal Sinus $\ldots \quad \ldots \quad \ldots \quad \ldots$

LAKYNX. - Speech without a Larynx.-Metastatic Abscesses in the

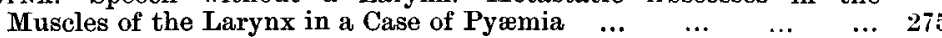

Esophagus. - Removal through the Mouth of a Tooth-plate impacted

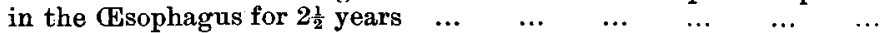

EAr.-The Resemblance of "Friedlander Otitis" to "Mucosus Otitis." -Operations for Mastoid Empyema and Caries.-The After-Treatment of Mastoid Operations.-Middle-ear Suppuration and Life $\begin{array}{llllllllll}\text { Insurance } & \ldots & \ldots & \ldots & \ldots & \ldots & \ldots & \ldots & \ldots & \ldots\end{array}$

Miscella neous.--Salvarsan in Lesions of the Nose and Throat. - Results obtained with Neo-salvarsan in Cases of Luetic Affections of the $\begin{array}{lllllllll}\text { Upper Air-Passages ... } & \cdots & \ldots & \ldots & \ldots & \ldots & \ldots & \ldots & 278\end{array}$

$\begin{array}{lllllllllll}\text { British Medical Association } & \ldots & \ldots & \ldots & \ldots & \ldots & \ldots & \ldots & 279\end{array}$

$\begin{array}{llllllllllll}\text { Notes and Queries } & \ldots & \ldots & \ldots & \ldots & \ldots & \ldots & \ldots & \ldots & 280\end{array}$

$\begin{array}{llllllllllll}\text { Books Received } & \ldots & \ldots & \ldots & \ldots & \ldots & \ldots & \ldots & \ldots & \ldots & 280\end{array}$
\end{abstract}


THE NORMAL TONSIL REPRESENTS A TYPE. Its Scientific Treatment Depends Absolutely upon a Clear Conception of what constitutes the Normal Type.

\section{THE TONSILS AND THE VOICE IN SCIENCE, SURGERY, SPEECH AND SONG.}

\section{By RICHARD B. FAULKNER, M.D.(Columbia University).}

This is the only systematic and classical work on the tonsils ever published. The only work that clearly defines and fully describes the normal tonsil; tells what it is, what it does, what deranges it, and how to cure it. The only work that teaches the principles of diagnosis and formulates the principles of treatment.

The same standard in education that requires an operator on the eye to have full knowledge of the anatomy and physiology of that organ, should apply with equal force to an operator on the tonsil. The positive determination of tiologic and pathologic factors is essential to a reasonable prognosis and a sound line of treatment. To cure the various diseases and to preserve the imp tonsil, requires the most accurate scientific discrimination between affections that are primary, secondary, symptomatic, reflex, mechanical and hyperplastic.

Prof. A. Jacobi: "Its learning is astounding; its aims and results are commonsensical and thoroughlv practical."

Prof. F. Massel : "Its interest-both for science and practice-is great."

Dr. Frank E. miller: "A veritable Opus Magnus that should be in every physician's library, within the reach of every voice specialist, singer and all interested in vocal art science, for its conclusions are so definitely drawn and so correct."

TWO DOLLARS, net. Four hundred pages. Illustrated. Cloth. Sent prepraid upon reccipt of price. Also through booksellers.

THE PRESBYTERIAN BOOK STORE, Distributors, 202, Fulton Building, Pittsburgh, Pa., U.S.A.

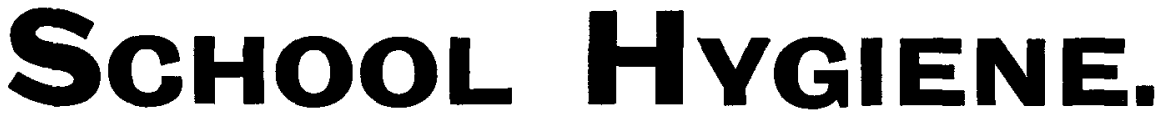

Published under the auspices of

The Medical Officers of Schools Association.

OUARTERLY. ANN. SUB. 4/6 post free.

AdLARD \& SON, BARTHOLOMEW Close, London, E.C.

\section{BRITISH JOURNAL OF CHILDREN'S DISEASES.}

Edited by J. D. ROLLESTON, M.D. MONTHLY. ANN. SUB. 20/- net, \$5, post free.

ADLARD \& SON, BARTHOLOMEW CLOSE, LONDON, E.C. 


\title{
HOSPITAL FOR \\ DISEASES OF THE THROAT,
}

GOLDEN SQUARE, LONDON, W.

\author{
HONORARY MEDICAL STAFF. \\ Consulting Surgeons $\left\{\begin{array}{l}\text { MR. MARK HOVELL. } \\ \text { DR. LAMBERT LACK. }\end{array}\right.$
}

Surgeons.

DR. J. W. BOND

MR. CHARLES PARKER

DR. FITZGERALD POWELL

Mr. FRANK ROSE ... ...

Mr. JEFFERSON FAULDER

MR. GEORGE BADGEROW

Assistant Surgeons.

Mr. NORMAN PATTERSON

Mr. CHARLES HOPE
Mr. LIONEL COLLEDGE

Dental Surgeon.

DR. J. W. PARE
Out.Patients.

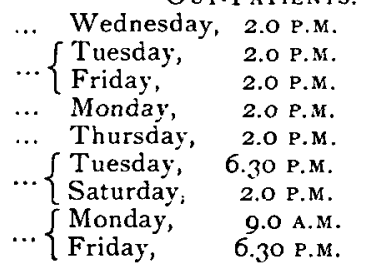

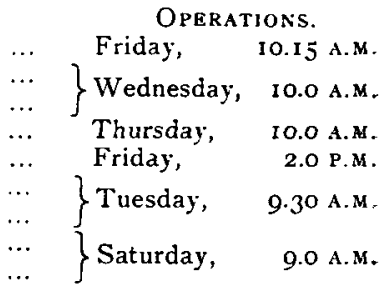
Attendances.

Monday, 9.0 A.M, Tuesday, 2.0 P.M., Friday, 2.0 P.M. Tuesday, 6.30 P.M., Wednesday, 2.0 P.M., Saturday, 2.0 P.M. Monday, 2.0 P.M., Thursday, 2.0 P.M., Friday, 6.30 P.M. Thursday, $9.30 \mathrm{A.M}$.

\section{CLINICAL INSTRUCTION.}

A Clinical Demonstration on the Diagnosis and Treatment of Selected Cases (Larynx, Nose, Ear) will be given each Monday at 5.30 p.m.

A Course in Surgical Anatomy and Physiology will be given each Thursday at 5.30 p.m. These Courses are free to Students of the Hospital. Others a fee of 2 guineas for each Course.

Practical Instruction in the Diagnosis and Treatment is given daily in the Out-patient Department from 2 to 5 p.m., on Tuesdays and Fridays from 6.30 p.m. to 9 p.m., and Mondays at 9.30 a.m.

Major Operations are performed at Io a.m. on Tuesday, Wednesday, Thursday, Friday, and Saturday, and Fridays at 2 p.m.

Minor Operations daily (Mondays excepted) at $9.30 \mathrm{a} . \mathrm{m}$.

Operative Surgery Classes. can be formed at any time on application.

Practice in Direct Laryngoscopy, Tracheoscopy, Bronchoscopy, and

Esophagoscopy will be given to Students, to enable them to become familiar with the use and manipulation of the instruments.

Practitioners and Medical Students are admitted to the Practice of the Hospital at a fee of five guineas for three months, eight guineas for six months, or ten guineas for a Perpetual Studentship. Each course may commence at any date. Special terms to men in actual practice who can only attend the hospital once or twice a week.

The Hospital contains 48 beds for In-patients. There is also an Out-patient attendance of nearly 50,000 yeariy.

Gentlemen may enter to the practice of The Throat Hospital at any time, and on certain conditions eligible for appointment as Clinical Assistants, whose duty it is to Assist the Member of the Staff to whom they are appointed.

GEORGE W. BADGEROW, F.R.C.S., Hon. Med. Sec. 